Zavarzin, G. \& Legunkova, R. (1959). J. gen. Microbiol. 21, 186-190

\title{
The Morphology of Nitrobacter winogradskyi
}

\author{
By G. ZAVARZIN AND RAISA LEGUNKOVA \\ Institute of Microbiology, Academy of Sciences, Moscor, U.S.S.R.
}

SUMMARY: The recently isolated organism of the second phase of nitrification is identified as Nitrobacter winogradskyi Buch. The organism reproduces by polar budding and possesses a distinct and easily demonstrated nucleus. The life cycle includes alternation of motile and non-motile stages. Motile cells possess a single flagellum which is 20 times longer than the cell body. The flagellum is laterally attached to the cell. The organism is related to the family Pasteuriaceae.

Until now only Nitrobacter spp. have been described as bringing about the second stage of nitrification. The morphological description of these organisms is incomplete. The mode of reproduction has not been described at all. Table 1 summarizes the data of those authors who have succeeded in pure culture isolation. The physiology of the isolated strains was the same and there was no doubt about the identity of these strains with that isolated by Winogradsky. Only Nelson (1931) differentiated his motile strain as $N$. agilis from the nonmotile $N$. winogradskyi.

Table 1. Nitrobacter morphology as described in literature

\begin{tabular}{|c|c|c|c|c|}
\hline Reference & $\begin{array}{l}\text { Size } \\
(\mu)\end{array}$ & $\begin{array}{l}\text { Form of } \\
\text { the cells }\end{array}$ & Motility & Note \\
\hline Winogradsky (1953) & $0.5 \times 1.0$ & $\begin{array}{l}\text { Prolongated pear- } \\
\text { shaped, the narrow end } \\
\text { is curved like a 'beak' }\end{array}$ & Non-motile & $\begin{array}{l}\text { Inside the cells } \\
\text { the grains are } \\
\text { stained }\end{array}$ \\
\hline Wimmer (1904) & $0.4 \times 1.0$ & Rod-like & Motile & - \\
\hline Gibbs (1919) & $0 \cdot 7 \times 1 \cdot 1$ & Oval & Non-motile & 一 \\
\hline Prouty (1929) & $0.8 \times 1 \cdot 0$ & Oval or spherical & Non-motile & - \\
\hline Nelson (1931) & $0.6 \times 0.9$ & Rod with polar flagella & Motile & N. agilis \\
\hline Kingma Boltjes (1936) & - & Ellipsoid & Non-motile & - \\
\hline Engel \& Skallau (1938) & $0.4 \times 1.0$ & Rod-like & Non-motile & Forms zoogloea \\
\hline Meiklejohn (1953) & $0.9 \times 1.1$ & Oval & Non-motile & - \\
\hline Zavarzin (1958) & $0.4 \times 1.1$ & $\begin{array}{l}\text { Pear-shaped, budding. } \\
\text { Single flagella }\end{array}$ & $\begin{array}{l}\text { Motile in } \\
\text { certain } \\
\text { stages of } \\
\text { developmen }\end{array}$ & $\begin{array}{l}\text { Possess } \\
\text { chromatin } \\
\text { grain }\end{array}$ \\
\hline
\end{tabular}

An organism which brought about the second stage of nitrification was isolated by Zavarzin (1958); the results of study of this organism were reported at the 7th International Congress for Microbiology (Stockholm) by Imšenecki (1958). During the discussion the question arose whether it was possible to classify this organism as Nitrobacter winogradskyi. The present paper concerns the results of electronmicroscopic study of isolated strains. 


\section{METHODS}

Two morphologically similar strains of Nitrobacter were isolated from rocks and soils of Middle Asia by means of a drop sprout method. Erlenmeyer flasks (50 ml.) containing Meiklejohn's (1953) medium were inoculated with small drops of enrichment culture. A drop was placed on the inner wall of a flask by a capillary pipette of such diameter that, on the average, a single organism would be found in each drop. About $3 \%$ of the subcultures were found to be pure.

The purity of the cultures was shown as follows. (1) By inoculation of nutrient media suitable for different physiological groups; about 20 different media were used. (2) By means of careful microscopic examination of cultures by phase-contrast microscopy. For the detection of Hyphomicrobium vulgare a method was developed which consisted in the inoculation of plates of Mevius medium solidified with agar. After incubation for 1 week at $28^{\circ}$ white colonies were seen. Pure cultures of Nitrobacter sp. were cultivated in a liquid medium containing (g./l.) 2, $\mathrm{NaNO}_{2} ; 0 \cdot 15, \mathrm{MgSO}_{4} 7 \mathrm{H}_{2} \mathrm{O} ; 0 \cdot 15, \mathrm{KH}_{2} \mathrm{PO}_{4} ; 0 \cdot 03, \mathrm{FeSO}_{4} 7 \mathrm{H}_{2} \mathrm{O}$; $0.5, \mathrm{CaCO}_{3}$; dissolved in tap water. No growth was observed on Bejerincks nitrite agar. The organisms from liquid cultures of different ages were centrifuged down and after fixation with osmium tetroxide and shadowing with chromium were examined by an electron-microscope.

\section{RESULTS}

The $\mathrm{OsO}_{4}$ fixed Nitrobacter organisms appeared not to be so pleomorphic as live organisms examined by phase contrast. The most common forms were oval or coin-shaped; these were dominant in the lag phase. Sometimes something resembling nucleus could be recognized (Pl. 1, fig. 1), but it was much more convenient to study chromatin bodies by the light microscope.

At the narrow end of the cell there was a small swelling which made the cell pear-shaped (Pl. 1, figs. 2-4). A terminal swelling gradually increased in size and a distinctly recognizable bud was formed. The bud was separated from the mother cell by a small isthmus (Pl. 1, fig. 4). An elastic cell wall seemed common for both cells (Pl. 1, fig. 3). During the further development the bud reached the size of the mother cell (Pl. 1, fig. 5, left). At this stage it was possible to find some cells with a single flagellum attached laterally, apparently to the daughter cell. Sometimes the flagellum reached $20 \mu$ in length. Plate 1 , fig. 5, represents an organism shortly before division, the second cell being the separated bud.

Motile Nitrobacter organisms were observed only during the logarithmic phase of growth, while the nitrite was not yet completely utilized. These organisms showed a rather slow swinging movement.

Thus, during multiplication, the bud was formed on the narrow end of the parent cell; this reached the size of the parent cell and then division took place. The bud possessed a single long flagellum.

The distribution of nuclear material in Nitrobacter cells was studied by means of the Feulgen reaction, double staining according to Peshkoff, staining 
with acetocarmine, Meyers haematoxylin, methyl green staining and by enzyme treatment. The nucleus in Nitrobacter cells may be demonstrated by staining with dilute fuchsin after acid hydrolysis which removed the chocolate-brown pigment. The results of applying all these methods were in agreement.

The mature cell and the bud from the very beginning of its formation contained the chromatic granules which corresponded in size to the sizes of the parent cell and the bud ( $\mathrm{Pl}$. 2, fig. 6).

In order to establish the identity of the isolated organism with that isolated by Winogradsky it was necessary to use the same methods of observation. Plate 2, fig. 7, represents the organisms from our culture stained with Ziehl fuchsin and Pl. 2, fig. 8, is an enlarged part of Winogradsky's photograph. The budding cells may be easily recognized on Winogradsky's micrograph made in 1891.

Consequently, it appears that the isolated strain of Nitrobacter may be classified as the species described by Winogradsky.

\section{Systematic position of Nitrobacter}

The reproduction by polar budding compels one to relate Nitrobacter to the family Pasteuriaceae order Caulobacteriales. The comparison of typical representatives of this group (Hyphomicrobium with Nitrobacter) is shown in Table 2.

Table 2. Comparison of Nitrobacter and Hyphomicrobium

\begin{tabular}{|c|c|c|}
\hline Organism & Hyphomicrobium & Nitrobacter \\
\hline Size $(\mu)$ & $0.5 \times 2.0$ & $0.4 \times 1.1$ \\
\hline Shape & Egg- or rod-shaped & Pear-shaped \\
\hline Appendages & $\begin{array}{l}\text { Branching filaments } \\
\text { ('stalks') }\end{array}$ & None \\
\hline Mode of reproduction & Polar budding & Polar budding \\
\hline Motility & The separated bud is motile & The separated bud is motile \\
\hline Chromatinic bodies & $\begin{array}{l}\text { Chromatin grains in mature } \\
\text { cells and buds }\end{array}$ & $\begin{array}{l}\text { Chromatin grains in mature } \\
\text { cells and buds }\end{array}$ \\
\hline Physiology & $\begin{array}{l}\text { Oxidation of simple organic } \\
\text { compounds } \\
\text { Chemosynthesis (?) }\end{array}$ & $\begin{array}{l}\text { Oxidation of nitrite to } \\
\text { nitrate } \\
\text { Chemosynthesis }\end{array}$ \\
\hline
\end{tabular}

An essential difference between Hyphomicrobium and Nitrobacter is the absence from Nitrobacter of the long polar filament ('caulus' of Henrici \& Johnson, 1935) at the tip of which the motile bud is formed by Hyphomicrobium. However, Henrici \& Johnson (1935) pointed out that some representatives of Pasteuriaceae possess a very short stalk or none.

\section{DISCUSSION}

Isolates of organisms which carry out the second stage of nitrification, except for the observation of motility, which is difficult to detect without modern methods, correspond to Winogradsky's description. But there is here a contradiction with other observations. If we exclude the possibility of incomplete 
observations, two alternatives arise: (1) Different workers have studied different stages of life-cycles of Nitrobacter. Nelson and Wimmer described a logarithmic phase of growth when the organism is motile while other authors have a fixed stationary phase. (2) Organisms which carry out the second stage of nitrification which are similar physiologically and differ in morphology. This difference includes not only different degree of motility but a different form of the cells from coccoid to rod-like.

Until the mode of reproduction of different Nitrobacter strains, particularly Nitrobacter agilis, is studied, it is impossible to conclude which hypothesis is correct and how many species of Nitrobacter have been studied. If the second supposition is justified, we shall find the most interesting case of physiological convergence.

The authors wish to thank Professor A. Imšenecki for encouragement during the work. They wish to thank Professors M. Alexander and T. Y. Kingma Boltjes and Dr Jane Meiklejohn for valuable discussions.

\section{REFERENCES}

Engel, H. \& Skallau, J. (1938). Die Reinkultur nitrifizierender Bakterien. Z Zbl. Bakt. II, 97, 305.

GibBS, D. (1919). The isolation and study of nitrifying bacteria. Soil Sci. 8, 127.

Henrici, A. \& Johnson, D. (1935). Studies on freshwater bacteria. Stalked bacteria, a new order of Schizomycetes. J. Bact. 30, 61 .

IMšENECKI, A. (1958). Physiology of nitrifying bacteria. 7th Int. Congr. Microbiol. Abstracts of Communications, p. 132.

Kingma Boltues, T. Y. (1936). Untersuchungen über die nitrifizierenden Bakterien. Arch. Mikrobiol. 7, 188.

Meiklejohn, J. (1953). The nitrifying bacteria. J. Soil Sci. 4, 59.

Nelson, D. (1931). Isolation and characterisation of Nitrosomonas and Nitrobacter. Zbl. Bkt. II, 83, 280.

Prouty, C. (1929). The use of dyes in the isolation of nitrite oxidizing bacteria. Soil Sci. 28, 125.

Wimmer, G. (1904). Beitrag zur Kentniss der Nitrifikationsbakterien. Z. Hyg. InfektKr. 48, 135.

Winogradsky, S. (1953). Mikrobiologia pochvi. Moscow: Isd. A.H.C.C.C.P.

Zavarzin, G. (1958). On the incitant of the second phase of nitrification. Microbiologia, 27, 679. (Russian, résumé English.)

\section{EXPLANATION OF PLATES}

\section{Plate 1}

Figs. 1-5 electronmicrographs shadowed with chromium. The same enlargement for all five pictures

Fig. 1. Coin-like cell of Nitrobacter; beginning of bud formation.

Fig. 2. The second stage of bud formation, appearance of the swelling.

Fig. 3. Appearance of the isthmus between bud and mother cell.

Fig. 4. Pear-shaped cell with completely formed bud.

Fig. 5. To the left, bud shortly before the separation from the mother cell; to the right, separated bud. The flagellum attached laterally may reach $20 \mu$ in length. 


\section{Plate 2}

Fig. 6. The distribution of nuclear substance in 5-day cultures. Nuclei are stained like granules at the wide part of the cells. Stained with dilute fuchsin after pigment had been removed. Light microscope.

Fig. 7. Nitrobacter stained with Ziehl fuchsin. The organisms are oval, sometimes pearshaped.

Fig. 8. Enlarged portion of centre of Winogradsky's micrograph (1953, Table 5, fig. 1). The budding is distinctly seen in some of the Nitrobacter organisms. The organisms indicated by arrows and numbers correspond to the electromicrographs of present paper.

(Received 4 February 1959) 
Journal of General Microbiology, Vol. 21, No. 1
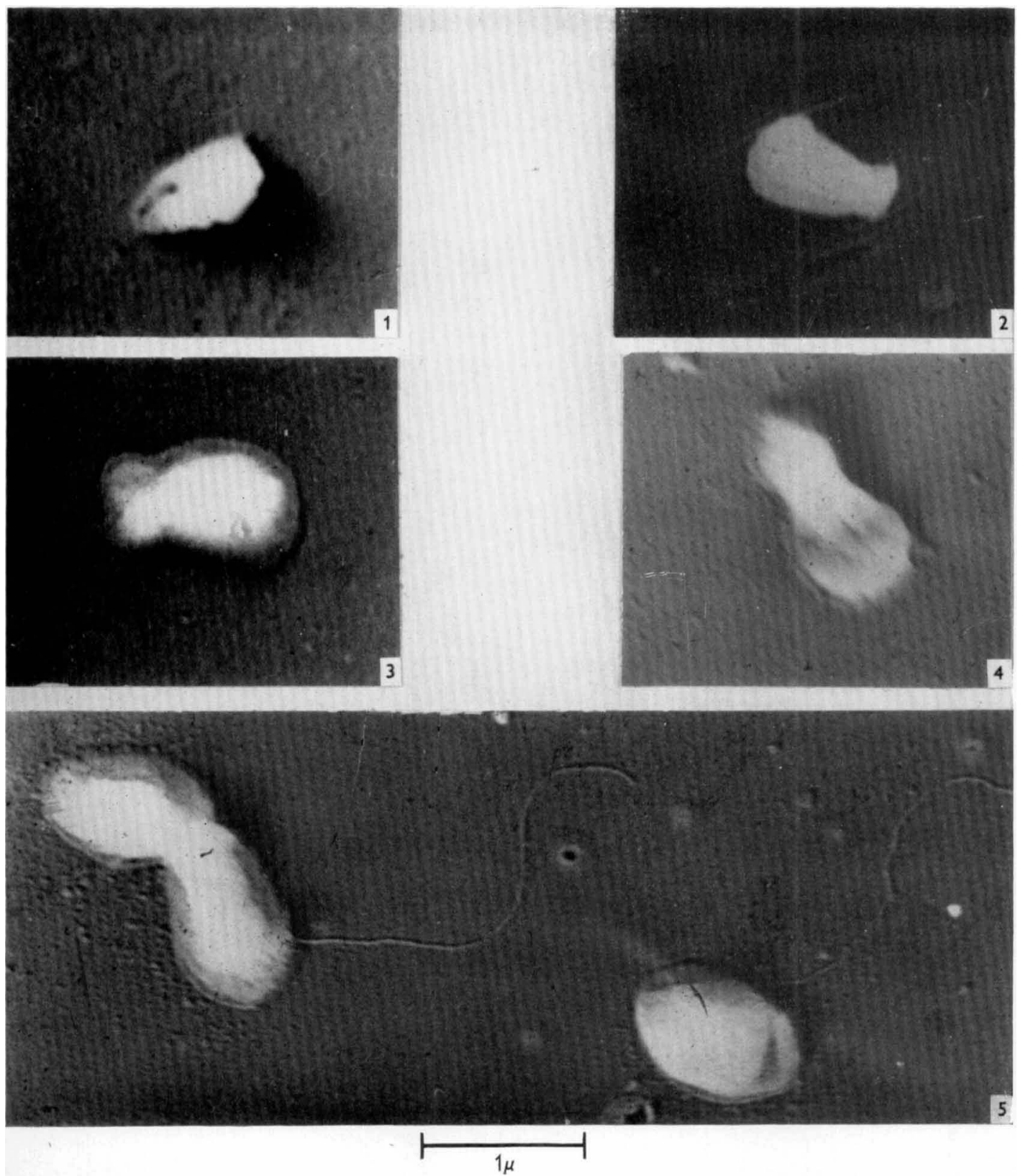

G. Zavarzin \& R. Legunkova-Nitrobacter winogradskyi. Plate: 1

(Faring $p .190$ ) 
Journal of General Microbiology, Vol. 21, No. 1

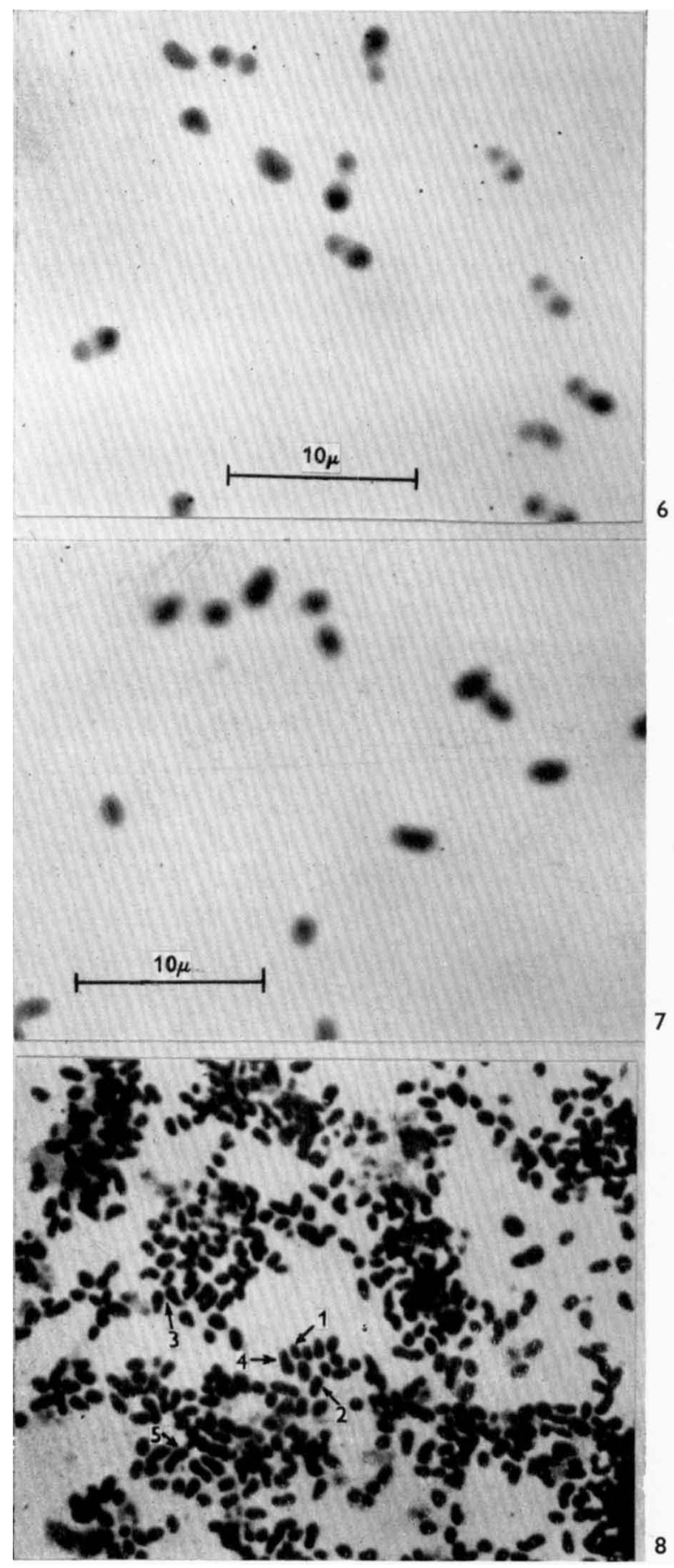

G. Zavarzin \& R. Legunkova-Nitrobacter winogradsky. Plate 2 